\title{
Surgically cured hypoglycemia secondary to pleural solitary fibrous tumour: case report and update review on the Doege-Potter syndrome
}

\author{
Ahmed Y Kalebi*1, Martin J Hale, Michelle L Wong2, Tessa Hoffman² and \\ Jill Murray ${ }^{3}$
}

Address: ${ }^{1}$ Department of Anatomical Pathology, National Health Laboratory Service [NHLS], Johannesburg, South Africa, ${ }^{2}$ Division of Pulmonology, University of the Witwatersrand, Johannesburg, South Africa and ${ }^{3}$ School of Public Health, National Institute of Occupational Healths, Johannesburg, South Africa

Email: Ahmed Y Kalebi* - ahmedkalebi@yahoo.com; Martin J Hale - martin.hale@nhsl.ac.za; Michelle L Wong - michelle.wong@wits.ac.za; Tessa Hoffman - thoffman12@hotmail.com; Jill Murray - jill.murray@nioh.nhls.ac.za

* Corresponding author

Published: 18 August 2009

Journal of Cardiothoracic Surgery 2009, 4:45 doi:10.1 186/I749-8090-4-45
Received: 14 June 2008

Accepted: 18 August 2009

This article is available from: http://www.cardiothoracicsurgery.org/content/4/I/45

(C) 2009 Kalebi et al; licensee BioMed Central Ltd.

This is an Open Access article distributed under the terms of the Creative Commons Attribution License (http://creativecommons.org/licenses/by/2.0), which permits unrestricted use, distribution, and reproduction in any medium, provided the original work is properly cited.

\begin{abstract}
The association of paraneoplastic hypoglycemia [Doege-Potter syndrome] and finger clubbing [Pierre-Marie-Bamberg syndrome] with pleural solitary fibrous tumour is rare. We present a previously unpublished but typical example of this rare occurrence together with a detailed updated literature review of previously published cases of pleural SFT discussing the histopathology of SFT; pathophysiology of the hypoglycemia and finger clubbing; treatment and outcome of pleural SFT. The patient, a 57-year-old African male was admitted at our hospital with recurrent episodes of hypoglycemia. He was found to have digital clubbing and decreased breath sounds in the right lower chest but no other significant clinical findings. His insulin level measured during an episode of hypoglycemia was undetectable. Chest radiograph and CT-scan revealed a lobulated mass in the right chest which was diagnosed to be SFT on histology. Surgical excision of the mass resulted in cure of the hypoglycemic episodes and rapid regression of the clubbing. Less than 65 cases of pleural SFT manifesting with hypoglycemia with or without finger-clubbing have been published in the English literature. The mean diameter of these tumours manifesting with hypoglycemia is 20 $\mathrm{cm}, 54 \%$ being benign while $42 \%$ were malignant. They predominantly present in the 6th-8th decade, average age of 64 years and a slight male preponderance at $58 \%$. Complete surgical resection remains the most important predictor of clinical outcome in terms of recurrence and metastases, while providing instant cure for the hypoglycemia and rapid resolution of the finger clubbing.
\end{abstract}

\section{Background}

The occurrence of hypoglycemia with an intrathoracic tumour was first reported by Doege and Potter independently in 1930 hence the eponym Doege-Potter syndrome [DPS] $[1,2]$. Hyperthrophic osteoarthropathy clinically observed as finger-clubbing is also associated with intrathoracic tumours and goes with the eponym of Pierre-Marie-Bamberg syndrome [PMBS]. In this report we present a previously unpublished but very typical example of the rare occurrence of hypoglycaemia and fin- 
ger-clubbing with pleural solitary fibrous tumour [SFT] in an adult African male. A detailed updated literature review is presented detailing the histopathology of SFT, pathophysiology of the hypoglycemia and finger clubbing, treatment and outcome of pleural SFT.

\section{Case Presentation}

A 57-year-old male was referred to the Chris Hani Baragwanath Hospital with recurrent episodes of symptoms of severe hypoglycemia including syncope. He had a 20 pack-year history of smoking. He was found on examination to have marked finger-clubbing and decreased breath sounds in the right lower chest, but no other significant clinical findings. Sputum cytology was negative for malignant cells. His blood glucose levels recorded over three consecutive days whilst remained low despite receiving continuous intravenous infusion of $10 \%$ dextrose (table 1). His serum insulin and C-peptide levels were also depressed (table 2). A chest radiograph and CT-scan showed a lobulated mass in the right chest suggestive of a benign pleural tumour (figure $1 \mathrm{AB}$ ).

A percutaneous needle biopsy of the mass showed morphological and immunohistochemical features of a benign SFT. The patient underwent thoracotomy with excision of the bulk of the mass. A small remnant attached to the diaphragm could not be removed. The tumour was large, well-circumscribed and encapsulated, with a tancoloured whorled cut surface (figure 1C1D). It weighed $1744 \mathrm{~g}$ and measured $20 \times 15 \times 10 \mathrm{~cm}$. There were no areas of intratumoral haemorrhage or necrosis.

Microscopic examination of the tumour revealed a bland spindle cell proliferation arranged in short intersecting fascicles with a patternless architecture, and hypo- and hypercellular areas separated by dense collagenous fibrous stroma (figure 1E). There was no evidence of cytological atypia or mitotic figures. Immunohistochemistry demonstrated that the tumour cells stained positive with CD34 (figure $1 \mathrm{~F}$ ) and $\mathrm{Bcl}-2$, while negative for $\mathrm{S} 100$, CD68, CD99, Calretinin, h-Caldesmon, MSA and SMA. Electron microscopy demonstrated ultrastructural features of fibroblasts with abundant collagen (figure 1Finset). A final diagnosis of pleural SFT was made.

The episodes of hypoglycemia abated postoperatively and the digital clubbing resolved within three months.

\section{Review}

\section{Methodology of literature search}

An extensive literature search on PUBMED was conducted using the key words SFT and its various synonyms to identify published cases of SFT. The search was then limited to reported cases of pleural based SFT with explicitly recorded hypoglycemia, with particular focus on the period from 1981 to 2008 . Unfortunately some authors did not record whether or not extrathoracic symptoms were present in their series [3]. Data from cases prior to 1981 were primarily traced from the review by Briselli et al which had analysed 360 cases in the literature and 8 additional cases from their series [4]. All reports that were traced in the English literature were extracted and the full articles scoured through to ascertain the cases of pleurothoracic SFT with hypoglycemia with or without fingerclubbing. These cases were then tabulated and are herein discussed.

\section{Results from the literature search}

We identified 48 cases of pleural SFT presenting with hypoglycemia that have been published since 1981 in the English literature. Briselli et al had previously reviewed 368 cases including their series of 8 cases from which they established that hypoglycemia was documented in $4 \%$ [4]. We therefore estimate that there are less than 65 cases of pleural SFT thus far published in the English literature.

Specific data available on the cases we reviewed since 1981 are outlined in table 3. Unfortunately individual data for patients with hypoglycemia was not recorded in some reports thus could not be analysed in this review [511] The patients' age range was 38 to 83 years, with an average of 64 years and a median of 65 years respectively. The majority of patients manifested hypoglycaemia in their $6^{\text {th }}$ to $8^{\text {th }}$ age decade. A slight male preponderance of $58 \%$ was noted. Interestingly we found that the youngest patient from our search, who happens to be the only under 40 years of age, was a 38 year old female who was diagnosed with 'pleural fibroma' while gravid at 13 weeks. Her hypoglycemia and finger clubbing resolved after surgery [12].

The average greatest dimension of these SFTs presenting with hypoglycemia as recorded since 1981 was $20 \mathrm{~cm}$ (table 3). England et al observed that 9/12 of the cases with hypoglycemia out of their series of 223 cases were greater than $10 \mathrm{~cm}$ in dimension [13]. The average weight of the tumours in our review was $2071 \mathrm{~g}$ with a range from $850 \mathrm{~g}$ to $4000 \mathrm{~g}$ (table 3). Malignant criteria [see under histopathology below] were fulfilled in $46 \%$ of the pleural SFT manifesting with hypoglycaemia while $54 \%$ were benign. Finger clubbing was noted in 22 cases [55\%] whereby the observation was documented. All the cases that we reviewed from 1981 were surgically managed. Complete surgical removal was achieved in all but one case. Surgical removal led to long-term recurrence free survival together with resolution of hypoglycemia and fingerclubbing in essentially all the cases reviewed.

\section{Histopathology of SFT}

Pleural SFT, first described as a distinct entity in 1931 [38], is an uncommon but not rare tumour. Well over 800 cases of pleural SFT have been reported in the medical lit- 

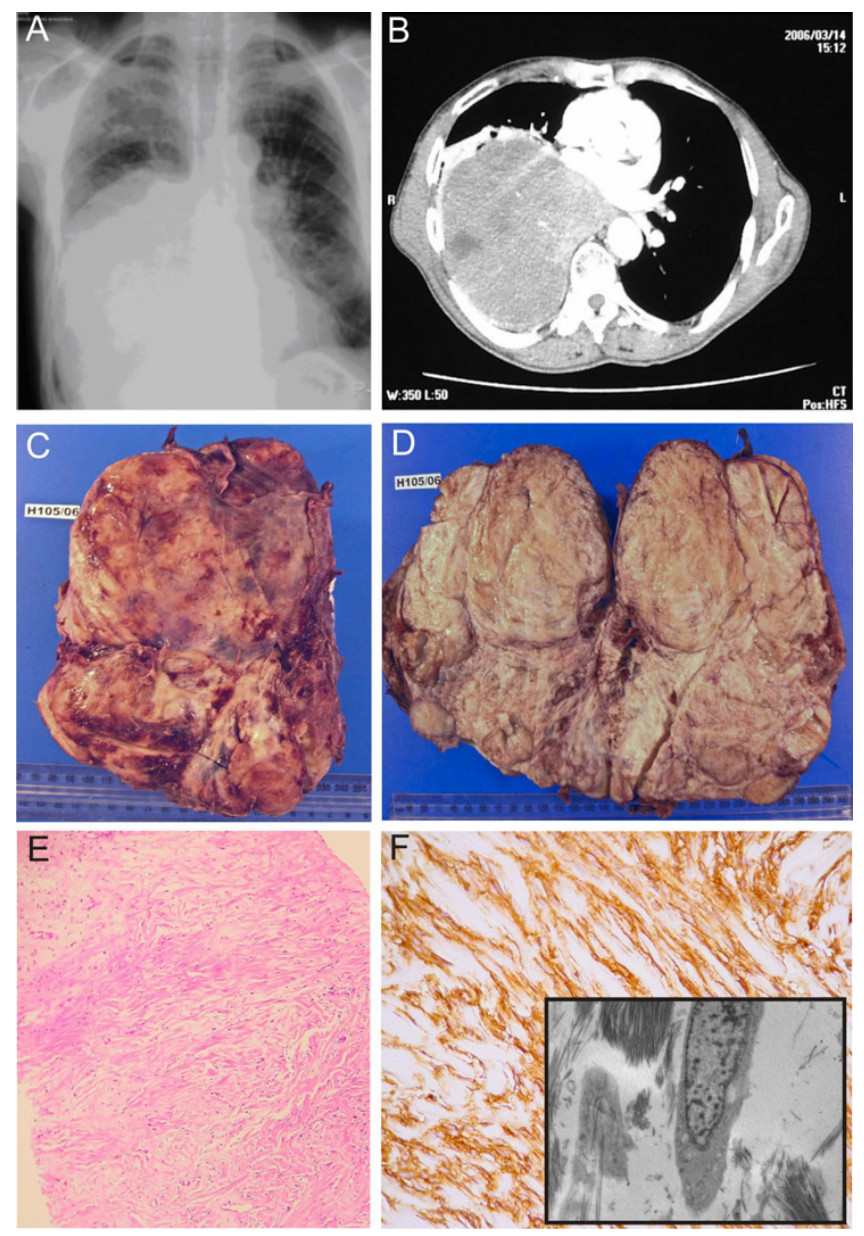

Figure I

I A: Chest radiograph showing a lobulated mass in the right chest suggestive of a benign pleural tumour. IB: CT-scan showing a lobulated mass in the right chest suggestive of a benign pleural tumour. IC: Tumour at macroscopy, well-circumscribed and encapsulated. ID: Cut surface of the tumour tan-coloured and whorled appearance. IE: Photomicrograph showing bland spindle cell proliferation with a patternless architecture, and hypo- and hypercellular areas separated by dense collagenous fibrous stroma (H\&E stain). IF: Photomicrograph of tumour cells stained positive with CD34. IF-inset: Electromicrograph depicting ultrastructural features of fibroblasts with abundant collagen.

erature, with many cases documented under synonyms or incorrect names [39-41]. Pleural SFT was considered to be of mesothelial origin, but recent evidence revealed it to be of mesenchymal histogenesis [42]. Extrathoracic SFT have thus been reported in the literature from sites such as the abdominal cavity, retroperitoneum, female genital tract, urinary tract and other sites, some of which may also be associated with hypoglycaemia [43-48].

At histology, pleural SFT is seen as a fibrous and myofibroblastic spindle cell neoplasm exhibiting a characteris- tic 'patternless' architecture, a typical hemangiopericytoma-like vascular network and positive staining for CD34 [42].

The aetiology of pleural SFT remains unknown and no association exists with smoking or asbestos exposure. The differential diagnosis for pleural SFT on histology includes other mesenchymal neoplasms characterized by a hemangiopericytoma-like vascular architecture. Previous synonyms of SFTs include fibrous mesothelioma, pleural fibroma, and sub-mesothelial fibroma. The WHO recommends that these should be discarded to avoid confusion and to denote the correct histogenesis [42].

At least $80 \%$ of all pleural SFTs are benign, while the rest may show local recurrence and metastases. Putative histological criteria for aggressive or malignant behaviour includes high mitotic activity [ $>4 / 10 \mathrm{HPF}]$, high cellularity, nuclear pleomorphism and necrosis $[13,42]$. However, the unfavourable histological features and tumour size in themselves are unreliable harbingers of poor clinical outcome $[13,17,49]$. Complete initial excision remains the most important indicator of clinical outcome for both benign and malignant pleural SFTs.

\section{Hypoglycemia in pleural SFT}

Hypoglycemia is rare in pleural SFT, occurring in approximately $5 \%$ of cases $[50,51]$. Doege was the first to associate this phenomenon with a pathological entity a spindle cell neoplasm that he noted to be slow growing which he called 'fibrosarcoma of the mediastiunum' a year before SFT was described by Klemperer and Rabin [38]. The pictures and photomicrographs in Doege's paper published in 1930 clearly show a striking resemblance to SFT [1].

Paraneoplastic hypoglycemia results from secretion of an unprocessed or incomplete high molecular weight [HMW] form of insulin-like growth factor type II [IGF-II] [52]. This HMW IGF-II is capable of activating insulin receptor thereby inhibiting hepatic gluconeogenesis and increasing peripheral glucose uptake which results in hypoglycaemia [53]. The HMW IGF-II is also capable of binding to IGF-I receptors leading to suppression of growth hormone by the pituitary, as well as reduction of insulin, IGF-I and IGF binding protein-3 by the pancreas [54].

Recently it has been shown that SFT cells have a markedly greater expression of IGF-II mRNA and a lesser expression of pro-hormone convertase 4 [PC 4] mRNA in the tumour tissue compared to normal placental tissue, raising the possibility that defective PC4 gene expression in these tumours may underlie the impaired processing of IGF-II [26]. Pro-hormone convertase 4 is an endoprotease involved in processing precursor HMW IGF-II that cleaves pro-IGF-II to generate the mature IGF-II $[55,56]$. The 
Table I: Patient's blood glucose recorded over three consecutive days from admission

\begin{tabular}{ll}
\hline Time & Capillary blood glucose level (mmol/L) \\
\hline 09 h 00 & 2.7 \\
\hline 13 h 00 & 4.6 \\
\hline$\underline{21 \text { h } 00}$ & $\underline{3.9}$ \\
\hline 01 h 00 & 1.8 \\
\hline 05 h 00 & 5.5 \\
\hline 09 h 00 & 4.8 \\
\hline I3 h 00 & 5.2 \\
\hline I7 h 00 & 9.4 \\
\hline 21 h 00 & $\underline{5.5}$ \\
\hline 01 h 00 & 1.8 \\
\hline 05 h 00 & 4.4 \\
\hline II h 00 & 2.4 \\
\hline I7 h 00 & 5.6 \\
\hline 21 h 00 & 3.1 \\
\hline
\end{tabular}

unprocessed HMW IGF-II has significantly higher bioavailability compared to mature or processed IGF-II, IGF-I and insulin, thus less able to complex serum IGF binding proteins hence its increased free levels $[57,58]$.

The detection of HMW IGF-II requires immunoblot analysis to distinguish it from normal IGF-II; unfortunately this technology was not available to us at the time and there was no pre-operative blood specimen preserved to enable IGF-II determination. Nevertheless all the features in this case fit with the diagnosis of DPS including severe intractable hypoglycemia with suppressed insulin secretion, decreased C-peptide and immediate resolution of the hypoglycemia following excision of the tumour.

Table 2: Patient's serum insulin and C-peptide levels before surgery

\begin{tabular}{ll}
\hline Blood glucose: & $2.2 \mathrm{mmol} / \mathrm{L}(4 . \mathrm{I} \quad \mathrm{II} . \mathrm{I} \mathrm{mmol} / \mathrm{L})$ \\
\hline Insulin: & $<2.0 \mathrm{mU} / \mathrm{L}(8.928 .4)$ \\
\hline C-peptide: & $0.7 \mu \mathrm{g} / \mathrm{L}(\mathrm{I} .15)$ \\
\hline Cortisol: & $394 \mathrm{nmol} / \mathrm{L}(250850)$ \\
\hline
\end{tabular}

Our review confirms the notion that hypoglycemia is a rare extrathoracic manifestation of pleural SFT with less than 65 cases representing approximately $57 \%$ out of over 900 estimated total number of cases thus far reported in the English literature. The reported incidence is extremely variable. England et al reported hypoglycemia in 12 out of 223 cases [5.2\%] from a multi-institutional case series $[13]^{3}$. Rena et al reported hypoglycemia in 3 out 21 cases [14.3\%] [5], Magdeleinat et al found only one case of hypoglycemia from a series of 60 cases [1.7\%] [6], and Chang et al found one out of 14 cases [7.1\%] in their series which at $33 \mathrm{~cm}$ also happened to be the largest tumour in that series [17]. On the other hand, Shung et al in a series of 63 cases [59], De Perrot et al in a series of 15 cases [60], and Perna et al with 8 cases [61], did not report a single case of hypoglycemia. As already mentioned, Briselli et al also did not have any single case of hypoglycemia in a series of 8 cases but established that hypoglycemia was documented in $4 \%$ of the 360 cases dating before 1981 [4].

Interestingly, onset of hypoglycemia in pleural SFT in one case coincided with the tumour growing to $13 \mathrm{~cm}$ over a period of 14 years of CT follow-up having grown y $5.5 \mathrm{~cm}$ in 7 years then $3.5 \mathrm{~cm}$ over another 7 years. The shortening of the tumour doubling time in these contrasting periods was suspected to be from the overproduction of tumour growth factors, including IGFII [25]. Over-expression of IGF-II mRNA is rarely observed for tumours with diameters less than $5 \mathrm{~cm} \mathrm{[62].} \mathrm{More} \mathrm{cases} \mathrm{of} \mathrm{hypoglyc-}$ emia occur with malignant SFT for tumours with diameters of $10 \mathrm{~cm}$ or more [13]. One of these cases recorded by England et al had fatal hypoglycemia as a direct metabolic consequence of pleural SFT [13].

The differential diagnosis of pleural based tumours presenting with hypoglycemia include other primary thoracic as well as metastatic non-islet cell epithelial and mesenchymal tumours [63]. The mesenchymal tumours include leiomyosarcoma, mesothelioma, haemangiopericytoma and the so-called malignant fibrous hustiocytoma [30,6466]. The primary epithelial tumours include squamous cell, large cell and bronchopulmonary adenocarcinoma, while hepatocellular, gastric and exocrine pancreatic carcinomas are the common metastatic tumours to the lung that may manifest with hypoglycemia $[67,68]$. Some of these paraneoplastic hypoglycemias in carcinomas are attributed to IGF-I rather than IGF-II [69].

\section{Hypertrophic osteoarthropathy in pleural SFT}

Hypertrophic osteoarthropathy (finger-clubbing) has been reported in $435 \%$ of patients with pleural SFT $[5,6,10]$. It is characterized by finger clubbing that is associated with hypertrophic skin changes, and periosteal bone changes. The paraneoplastic manifestation of finger- 
Table 3: Age, Gender, Weight, Size and Histology of pleural SFT in the literature [12-37]

\begin{tabular}{|c|c|c|}
\hline \multirow[t]{3}{*}{ Age $(n=30)$} & Mean & 63.5 years \\
\hline & Median & 64.5 years \\
\hline & Range & 3883 years \\
\hline \multirow[t]{2}{*}{ Gender $(n=40)$} & Males & $23(58 \%)$ \\
\hline & Females & $17(43 \%)$ \\
\hline \multirow[t]{3}{*}{ Weight $(n=18)$} & Mean & $207 \mathrm{Ig}$ \\
\hline & Median & $1822 \mathrm{~g}$ \\
\hline & Range & $8504000 \mathrm{~g}$ \\
\hline \multirow[t]{3}{*}{ Maximum size $(n=24)$} & Mean & $20.2 \mathrm{~cm}$ \\
\hline & Median & $20.0 \mathrm{~cm}$ \\
\hline & Range & $1033 \mathrm{~cm}$ \\
\hline \multirow[t]{2}{*}{ Histological criteria $(n=39)$} & Benign & $21(54 \%)$ \\
\hline & Malignant & $18(46 \%)$ \\
\hline Finger clubbing $(n=40)$ & Recorded in 22 cases (55\%) & \\
\hline
\end{tabular}

clubbing secondary to thoracic SFT is eponymously referred to as Pierre-Marie-Bamberg syndrome [PMBS]. Reports in literature indicate that finger-clubbing in pleural SFT is more common than hypoglycaemia $[13,39,30]$. The pathophysiology of finger-clubbing remains unascertained but it is postulated that the underlying HOA results from abnormal production of hyaluronic acid by the tumour cells resulting in periosteal changes, chronic hypoxia and paraneoplastic secretion of cytokines such as VEGF and PDGF. Though our patient had a history of smoking, it is the excision of the tumour that led to rapid and complete resolution of the finger-clubbing. This observation is consistent with previously published observations.

\section{Treatment and prognosis of pleural SFT}

It is obvious from the good results reported in the literature that surgery is the treatment of choice for both malignant and benign pleural SFTs including those presenting with hypoglycemia \pm finger-clubbing. Hypoglycemia and finger-clubbing almost always completely resolve following surgical excision, usually with no complications, but the symptoms may recur with recurrence of the lesion [5]. The local recurrence rate of pleural SFT following surgery is excellent for benign pleural SFT [recurrence rate $2 \%$ up to $8 \%$ ] but varies widely for malignant pleural SFTs with a range of $14 \%$ for grossly pedunculated histologically malignant tumours, and up to $68 \%$ for sessile histologically malignant tumours, reflecting the importance of complete excision [39,70-72]. It is important to keep in mind that pleural SFT presenting with hypoglycemia tend to be remarkably large-sized as shown from data presented in this review (table 3 ). These tumours manifesting as DPS should therefore be excised intact en bloc with clear margins to avoid recurrence [27].

Radiotherapy and chemotherapy have limited value in the curative treatment of pleural SFT because complete surgical excision is the best treatment. Nevertheless, radiotherapy and chemotherapy have been advocated for adjuvant treatment when resection is incomplete or impossible especially for histologically malignant tumours, as well as for recurrences, [39,73]. Neoadjuvant chemo-radiation with selective embolisation has been used successfully to reduce tumour bulk and alleviate hypoglycemia in a patient with previously irresectible abdominal SFT that responded and became amenable complete surgical resection [74]. Symptomatic medical treatment of hypoglycemia has been tried with some success for patients unfit for surgery $[52,74]$. 
Long term [510 years] survival rates for pleural SFT vary from $75 \%$ to $100 \%$ in various series $[6,13,39,72]$. Most recurrences tend to occur within 24 months of initial resection but may happen even after more than 1520 years. All cases of pleural SFT should be followed-up with periodic chest CT scans [ 6 monthly to yearly] in order to monitor for recurrence, particularly those that fall in the malignant category and those that were difficult to excise [11]. Malignant transformation in recurrence of previously benign pleural SFT has been reported [75,76]. Surgical re-excision of the recurrences where possible remains the preferred treatment $[77,78]$.

\section{Conclusion}

Pleural SFT is an uncommon but not rare tumour that is now known to be of mesenchymal fibroblastic rather than mesothelial origin. Paraneoplastic manifestation of hypoglycemia and finger-clubbing in pleural SFT are exceedingly rare yet important clinical features in terms of diagnosis and follow-up. Hypoglycemia with or without finger-clubbing has been recorded in $<80$ cases in the English Literature. Both hypoglycemia and finger-clubbing resolve following excision of the tumour. In this updated review, hypoglycemia with and without finger-clubbing was found to associated with large tumours $[>10 \mathrm{~cm}]$, but does not appear to be significantly associated with histological features of malignancy. The hypoglycemia is caused by HMW IGF-II which results from defective enzymes due to PC4 gene abnormalities in the tumour cells. The finger-clubbing results from abnormal hyaluronic acid deposition due to VEGF and PDGF cytokine expression. Histological features for malignancy and size, though important, are not truly predictive of local recurrence or worse clinical outcome. Complete surgical excision of the tumour remains the best treatment and most important predictor of clinical outcome. Longterm follow-up is recommended due to varyingly high recurrence rates particularly for tumours that were difficult to completely excise and have histological features for aggressive or malignant behaviour.

\section{Abbreviations}

CT: Computed tomography; DPS: Doege-Potter syndrome; IGF: Insulin-like growth factor; HMW: High molecular weight; HOA: Hypertrophic osteoarthropathy; MSA: Muscle-specific acting, PDGF: Platelet-derived growth factor; PMBS: Pierre Marie-Bamberg syndrome; SFT: Solitary fibrous tumour; SMA: Smooth muscle acting; VEGF: Vascular endothelial growth factor; WHO: World Health Organisation.

\section{Competing interests}

The authors declare that they have no competing interests.

\section{Authors' contributions}

All authors helped to draft the manuscript, read and approved the final manuscript. AK, MJH and JM were involved in making the pathological diagnosis. MW and $\mathrm{TH}$ were involved in the case report, clinical workup and management of the patient. AK and JM did the literature search and review. AK coordinated the drafting of the manuscript and its preparation for publication.

\section{Consent Statement}

Written informed consent was obtained through the University of the Witwatersrand Ethics Committee for publication of this case report and accompanying images. A copy of the written consent is available for review by the Editor-in-Chief of this journal.

\section{Acknowledgements}

Dr J. Phillips for the electron micrographs and Mr. Eric Liebenberg for help with photography and imaging. The case report was presented at the 2006 Biennial Congress of the Association of Pathologists of East, Central and Southern Africa [APECSA].

\section{References}

I. Doege KW: Fibrosarcoma of the Mediastinum. Ann Surg 1930, 92:955.

2. Potter RE: Intrathoracic tumors. Radiology 1930, 14:60-2.

3. Hiraoka K, Morikawa T, Ohbuchi T, Katoh H: Solitary fibrous tumors of the pleura: clinicopathological and immunohistochemical examination. Interact Cardiovasc Thorac Surg 2003, 2:6I-4. [Comment to article]

4. Briselli M, Mark EJ, Dickersin GR: Solitary fibrous tumor of the pleura: eight new cases and review of $\mathbf{3 6 0}$ cases in the literature. Cancer 198I, 47:2678-89.

5. Rena O, Filosso PL, Papalia E, Molinatti M, Di Marzio P, Maggi G, Oliaro A: Solitary fibrous tumour of the pleura: surgical treatment. Eur J Cardio-thorac Surg 200 I, 19:185-I89.

6. Magdeleinat P, Alifano M, Petino A, Le Rochais JP, Dulmet E, Francoise G, Icard P, Regnard JF: Solitary fibrous tumors of the pleura: clinical characteristics, surgical treatment and outcome. Eur J Cardio-thorac 2002, 21:1087-1093.

7. Burgess KR, Rutland J, Marlin GE, Maloney PJ, Perry DC: Benign pleural mesothelioma with tumour-induced hypoglycaemia. Aust N Z J Med 1982, I 2:70-2.

8. Roy TM, Burns MV, Overly DJ, Curd BT: Solitary fibrous tumor of the pleura with hypoglycemia: the Doege-Potter syndrome. J Ky Med Assoc 1992, 90:557-60.

9. Suter $M$, Gebhard S, Boumghar M, Peloponisios $N$, Genton $C Y$ : Localized fibrous tumours of the pleura: 15 new cases and review of the literature. Eur J Cardio-thorac 1998, 14:453-459.

10. Cardillo O, Facciolo F, Cavazzana AD, Capece O, Oasparri R, Martelli $M$ : Localized [solitary] fibrous tumours of the pleura: an analysis of 55 patients. Ann Thorac Surg 2000, 70:1808-1812.

II. Kohler M, Clarenbach CF, Kestenholz P, Kurrer M, Steinert HC, Russi EW, Weder W: Diagnosis, treatment and long-term outcome of solitary fibrous tumours of the pleura. Eur J Cardiothorac 2007, 32:403-408.

12. Schweichler M, Hennessey JV, Cole P, Perdue JF, Le Roith D: Hypoglycemia in pregnancy secondary to a non-islet cell tumor of the pleura and ectopic insulin-like growth factor II hormone production. Obstet Gynecol 1995, 85:810-3.

13. England DM, Hochholzer L, McCarthy MJ: Localized benign and malignant fibrous tumors of the pleura. A clinicopathologic review of 223 cases. Am J Surg Pathol 1989, 13:640-58.

14. Touyz R, Plitt M, Rumbak M: Hypoglycemia associated with a lung mass. Chest 1986, 89:289-90. 
15. Cole FH Jr, Ellis RA, Goodman RC, Weber BC, Courington DP Benign fibrous pleural tumor with elevation of insulin-like growth factor and hypoglycemia. South Med J 1990, 83:690-4.

16. Sakamoto T, Kaneshige $H$, Takeshi A, Tsushima T, Hasegawa $S$ Localized pleural mesothelioma with elevation of high molecular weight insulin-like growth factor II and hypoglycemia. Chest 1994, 106:965-7.

17. Chang YL, Lee YC, Wu CT: Thoracic solitary fibrous tumor: clinical and pathological diversity. Lung Cancer 1999, 23:53-60.

18. Chaugle H, Parchment C, Grotte GJ, Keenan DJM: Hypoglycaemia associated with a solitary fibrous tumour of the pleura. Eur J Cardiothorac 1999, 15:84-86.

19. Chamberlain MH, Taggart DP: Solitary Fibrous Tumor Associated with Hypoglycemia: An Example of the Doege-Potter Syndrome. J Thorac Cardiovasc Surg 2000, I I 9: 185-7.

20. Chang JC, Su KY, Chao SF, Hsu YH, Yang GG, Chang BS: Hypoglycemia in a patient with a huge malignant solitary fibrous tumor of the pleura. J Korean Med Sci 200I, 16:220-4.

21. Kishi K, Homma S, Tanimura S, Matsushita H, Nakata K: Hypoglycemia induced by secretion of high molecular weight insulinlike growth factor-II from a malignant solitary fibrous tumor of the pleura. Intern Med 200I, 40:34I-4.

22. Hirai A, Nakanishi R: Solitary fibrous tumor of the pleura with hypoglycemia associated with serum insulin-like growth factor II. J Thorac Cardiovasc Surg 2006, 132:713-4.

23. D'Andrilli A, Andreetti C, Ibrahim M, Rendina MA: The evolution of a pleural nodule into a giant fibrous tumour associated with hypoglycemic coma. Eur J Cardio-thorac Surg 2007, 31:955-957.

24. Fridlington J, Weaver J, Kelly B, Kelly E: Secondary hypertrophic osteoarthropathy associated with solitary fibrous tumor of the lung. J Am Acad Dermatol 2007, 57(5 Suppl):SI06-10.

25. Kameyama K, Okumura N, Kokado Y, Miyoshi K, Matsuoka T, Nakagawa T: Solitary fibrous tumor associated with non-islet cell tumor hypoglycemia. Ann Thorac Surg 2007, 84(I):292-4.

26. Tani $Y$, Tateno $T$, Izumiyama $H$, Doi M, Yoshimoto $T$, Hirata $Y$ : Defective Expression of Prohormone Convertase 4 and Enhanced Expression of Insulin-like Growth Factor II by Pleural Solitary Fibrous Tumor Causing Hypoglycemia. Endocr J 2008, 55:905-II.

27. Foroulis CN, Rammos KS, Tsomkopoulos S, Sileli MN, Hatzibougias I, Papakonstantinou C: Fibrous tumor of the lung: diagnostic and therapeutic considerations apropos of two cases. J BUON 2008, I3:I |7-2I.

28. Chang JC, Su KY, Chao SF, Hsu YH, Yang GG, Chang BS: Hypoglycemia in a patient with a huge malignant solitary fibrous tumor of the pleura. Pathol Int 2007, 57:79I-3.

29. Kinoshita T, Ishii K, Miyasato S: Localized pleural mesothelioma: CT and MR findings. Magn Reson Imaging 1997, 15:377-9.

30. Herrmann BL, Saller B, Kiess W, Morgenroth K, Drochner K, Schröder T, Mann K: Primary malignant fibrous histiocytoma of the lung: IGF-II producing tumor induces fasting hypoglycemia. Exp Clin Endocrinol Diabetes 2000, 108:515-8.

31. Mandal AK, Rozer MA, Salem FA, Oparah SS: Localized benign mesothelioma of the pleura associated with a hypoglycemic episode. Arch Intern Med 1983, I43:1608-10.

32. Mohamed H, Mandal AK: Natural history of multifocal solitary fibrous tumors of the pleura: a 25 -year follow-up report. J Natl Med Assoc 2004, 96:659-62.

33. Balduyck B, Lauwers P, Govaert K, Hendriks J, De Maeseneer M, Van Schil P: Solitary fibrous tumor of the pleura with associated hypoglycemia: Doege-Potter syndrome: a case report. J Thorac Oncol 2006, I:588-90.

34. Moat NE, Pawade A, Lewis BC, Shore G, Lamb RK, Monro J]: Spontaneous hypoglycaemia and pleural fibroma: role of insulinlike growth factors. Thorax 1991, 46:932-33.

35. Adhami N, Ahmed R, Lento PA, Shimshi M, Herman SD, Teirstein AS: Fibrous pleural tumor with hypoglycemia: case study. $M t$ Sinai J Med 2004, 7 1:344-6.

36. Kulinna-Cosentini C, Brunner C, Klepetko W, Dekan G, Bankier A Incidental discovery of a large thoracic mass in a 65 -year-old dentist. Solitary localized fibrous tumor of the pleura. Respiration 2008, 75: 109-12.

37. Stein RH, Herman SD, Phelps RG, Sapadin AN: Florid eruption of seborrheic keratoses associated with elevated insulin-like growth factor, hypoglycemia, and solitary fibrous tumor of the pleura. Int J Dermatol 2004, 43:944-7.

38. Klemperer P, Rabin CB: Primary neoplasms of the pleura. Arch Pathol I93I, I I:386-4II.

39. De Perrot M, Kurt AM, Robert H, Borish B, Spiliopoulos A: Clinical behaviour of solitary tumours of the pleura. Ann Thorac Surg 1999, 67: | 456-1459.

40. Robinson LA: Solitary fibrous tumor of the pleura. Cancer Control 2006, 13:264-9.

4I. Khan JH, Rahman SC, Clary-Marcy C, Kerlan KK, George TI, Hall TS, Jablous DM: Giant solitary fibrous tumour of the pleura. Ann Thorac Surg 1998, 65: | 461-1 464.

42. Travis WD, Brambilla E, Muller-Hermelin HK, Harris CC, [Eds]: World Health Organization Classification of Tumours. Pathology and Genetics of Tumours of the Lung, Pleura, thymus and Heart. Lyon: IARC Press; 2004:142-3.

43. Yi B, Bewtra C, Yussef K, Silva E: Giant pelvic solitaryfibrous tumor obstructing intestinal and urinary tract: a case report and literature review. Am Surg 2007, 73:478-80.

44. Muñoz E, Prat A, Adamo B, Peralta S, Ramón y Cajal S, Valverde C: A rare case of malignant solitary fibrous tumor of the spinal cord. Spine 2008, 33:E397-9.

45. Akisue T, Matsumoto K, Kizaki T, Fujita I, Yamamoto T, Yoshiya S, Kurosaka M: Solitary fibrous tumor in the extremity: case report and review of the literature. Clin Orthop Relat Res 2003, 4II:236-44.

46. Chan G, Horton PJ, Thyssen S, Lamarche M, Nahal A, Hill DJ, Marliss $\mathrm{EB}$, Metrakos P: Malignant transformation of a solitary fibrous tumor of the liver and intractable hypoglycaemia. J Hepatobiliary Pancreat Surg 2007, 14:595-9.

47. Wakami $\mathrm{K}$, Tateyama $\mathrm{H}$, Kawashima $\mathrm{H}$, Matsuno $\mathrm{T}$, Kamiya $\mathrm{Y}$, Jin-No Y, Kimura G, Eimoto T: Solitary fibrous tumor of the uterus producing high-molecular-weight insulin-like growth factor II and associated with hypoglycemia. Int J Gynecol Pathol 2005, 24:79-84.

48. Lucas CE, Ledgerwood AM: Malignant solitary fibrous tumor of the intestine with refractory hypoglycemia [Doege Potter Syndrome]. J Am Coll Surg 2006, 203:398.

49. Hanau CA, Miettinen M: Solitary fibrous tumor: histological and immunohistochemical spectrum of benign and malignant variants presenting at different sites. Hum Pathol 1995, 26:440-9.

50. Graadt van Roggena JF, Hogendoorn PCW: Solitary fibrous tumour: the emerging clinicopathologic spectrum of an entity and its differential diagnosis. Current Diagnostic Pathology 2004, 10:229-235.

51. Zafar H, Takimoto $\mathrm{CH}$, Weiss G: Doege-Potter syndrome: hypoglycemia associated with malignant solitary fibrous tumor. Med Oncol 2003, 20:403-8.

52. Tsuro K, Kojima H, Okamoto S, Yoshiji H, Fujimoto M, Uemura M, Yoshikawa M, Nakamura T, Kou S, Nakajima Y, Fukui H: Glucocorticoid therapy ameliorated hypoglycemia in insulin-like growth factor-II-producing solitary fibrous tumor. Intern Med 2006, 45:525-9.

53. Daughaday WH, Trivedi B: Meaurement of derivatives of proinsulin-like growth factor-II in serum by a radioimmunoassay directed against the E-domain in normal subjects and patients with nonislet cell tumor hypoglycemia. J Clin Endocrinol Metab 1992, 75: I I0-5.

54. Roith DL: Tumor-induced hypoglycemia. N Engl J Med 1999, 341:757-8.

55. Duguay S, Jin Y, Stein J, Duguay AN, Gardner P, Steiner DF: Posttranslational processing of the insulin-like growth factor-2 precursor. Analysis of O-glycosylation and endoproteolysis. Biol Chem 1998, 273:I8443-1845I.

56. Qiu Q, Basak A, Mbikay M, Tsang BK, Gruslin A: Role of pro-IGFII processing by proprotein convertase 4 in human placental development. Proc Natl Acad Sci USA 1 02: I I 047-I I 052.

57. Frystyk J, Skjaerbaek C, Zapf J, Orskov H: Increased levels of circulating free insulin-like growth factors in patients with nonislet cell tumour hypoglycemia. Diabetologia 1998, 41:589-594.

58. Bond J], Meka S, Baxter RC: Binding characteristics of pro-insulin-like growth factor-II from cancer patients: binary and ternary complex formation with IGF binding proteins-I to -6 . Endocrinol 2000, 165:253-260. 
59. Sung SH, Chang JW, Kim J, Lee KS, Han J, Park SI: Solitary fibrous tumors of the pleura: surgical outcome and clinical course. Ann Thorac Surg 2005, 79:303-7.

60. De Perrot M, Perna V, Rivas F, Morera R, Saumench J, Ramos R, Macia I, Ureña A, Escobar I, Villalonga R, Moya J: Localized [solitary] fibrous tumors of the pleura: an analysis of 15 patients. Int $J$ Surg 2008, 6:298-30I.

61. Perna V, Rivas F, Morera R, Saumench J, Ramos R, Macia I, Ureña A, Escobar I, Villalonga R, Moya J: Localized [solitary] fibrous tumors of the pleura: an analysis of I5 patients. Int J Surg 2008, 6:298-30I.

62. Lloyd RV, Erickson LA, Nascimento AG, Kloppel G: Neoplasms causing nonhyperinsulinemic hypoglycemia. Endocr Pathol 1999, 10:291-7.

63. Froesch ER, Zapf J, Windner U: Hypoglycaemia associated with noninslet cell tumor and insulin-like growth factors. $N$ Engl J Med 1982, 306:1178-1179.

64. Le Roith D: Tumor-induced hypoglycemia. N Engl J Med I999, 34:757-8.

65. Daughaday WH, Emanuele MA, Brooks MH, Barbato AL, Kapadia M, Rotwein P: Synthesis and secretion of insulin-like growth factor II by a leiomyosarcoma with associated hypoglycemia. $\mathrm{N}$ Engl J Med 1988, 3 19: 1434-40.

66. Höög A, Sandberg Nordqvist AC, Hulting AL, Falkmer UG: Highmolecular weight IGF-2 expression in a haemangiopericytoma associated with hypoglycaemia. APMIS 1997, 105:469-82.

67. Jayaprasad N, Anees T, Bijin T, Madhusoodanan S: Severe hypoglycemia due to poorly differentiated hepatocellular carcinoma. J Assoc Physicians India 2006, 54:4I 3-5.

68. Nauck MA, Reinecke M, Perren A, Frystyk J, Berishvili G, Zwimpfer C, Figge AM, Flyvbjerg A, Lankisch PG, Blum WF, Klöppel G, Schmiegel W, Zapf J: Hypoglycemia due to paraneoplastic secretion of insulin-like growth factor-I in a patient with metastasizing large-cell carcinoma of the lung. J Clin Endocrinol Metab 2007, 92:1600-5.

69. Daughaday WH: Hypoglycemia due to paraneoplastic secretion of insulin-like growth factor-I. J Clin Endocrinol Metab 2007, 92:1616.

70. Schirosi L, Lantuejoul S, Cavazza A, Murer B, Yves Brichon P, Migaldi M, Sartori G, Sgambato A, Rossi G: Pleuro-pulmonary solitary fibrous tumors: a clinicopathologic, immunohistochemical, and molecular study of 88 cases confirming the prognostic value of de Perrot staging system and p53 expression, and evaluating the role of c-kit, BRAF, PDGFRs [alpha/beta], cmet, and EGFR. Am / Surg Pathol 2008, 32(I I):1627-42.

7I. Brozzetti S, D'Andrea N, Limiti MR, Pisanelli MC, De Angelis R, Cavallaro A: Clinical behavior of solitary fibrous tumors of the pleura. An immunohistochemical study. Anticancer Res 2000, 20:470I-6.

72. Carretta A, Bandiera A, Melloni G, Ciriaco P, Arrigoni G, Rizzo N, Negri G, Zannini P: Solitary fibrous tumour of the pleura: immunohistochemical analysis and evaluation of prognostic factors after surgical treatment. J Surg Oncol 2006, 94(I):40-4

73. Veronesi G, Leo F, Solli PG, D'Aiuto M, D'Ovidio F, Mazzarol G, Spaggiari L, Pastorino U: Huge malignant localized fibrous tumor of the pleura. J Cardiovasc 2000, 41:78I-784.

74. de Boer J, Jager PL, Wiggers T, Nieboer P, Machteld Wymenga AN, Pras E, Hoogenberg K, Sleijfer DT, Suurmeijer AJ, Graaf WT van der: The therapeutic challenge of a nonresectable solitary fibrous tumor in a hypoglycemic patient. Int J Clin Oncol 2006, I I (6):478-8I.

75. Kanthan R, Torkian B: Recurrent solitary fibrous tumor of the pleura with malignant transformation. Arch Pathol Lab Med 2004, I 28:460-2.

76. Krishnadas R, Froeschle PO, Berrisford RG: Recurrence and malignant transformation in solitary fibrous tumour of the pleura. Thorac Cardiovasc Surg 2006, 54:65-7.

77. Gold JS, Antonescu CR, Hajdu C, Ferrone CR, Hussain M, Lewis JJ, Brennan MF, Coit DG: Clinicopathologic correlates of solitary fibrous tumors. Cancer 2002, 94:1057-1068.

78. Santos RS, Haddad R, Lima CE, et al.: Patterns of recurrence and long-term survival after curative resection of localized fibrous tumors of the pleura. Clin Lung Cancer 2005, 7:197-20I. Publish with Bio Med Central and every
scientist can read your work free of charge

"BioMed Central will be the most significant development for disseminating the results of biomedical research in our lifetime. "

Sir Paul Nurse, Cancer Research UK

Your research papers will be:

- available free of charge to the entire biomedical community

- peer reviewed and published immediately upon acceptance

- cited in PubMed and archived on PubMed Central

- yours - you keep the copyright

Submit your manuscript here:

http://www.biomedcentral.com/info/publishing_adv.asp
BiolMedcentral 